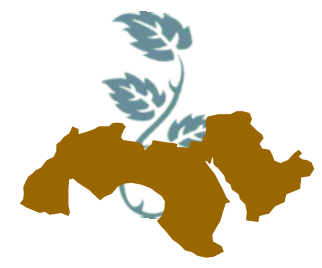

645

Arab Univ.

J. Agric. Sci., Ain Shams Univ., Cairo, 24(2), 645-652, 2016

\title{
DEFINITION OF DANGEROUS MICROBES CONTAMINATED WHITE COATS FOR STUDENTS OF HEALTH COLLEGES AND SCIENCE
}

\author{
Latifah AL-Hussainin \\ Biology Dept., Fac. of Sci., Princess Nora Bint Abdul Rahman Univ., Kingdom of Saudi \\ Arabia (LAALhusnain @pnu.edu.sa)
}

Keywords: Clothing, Bacteria, Fungi, White coats, students, laboratory, Vitek analyser. Sensitivity test

\begin{abstract}
White coats worn by professionals in the medical field (students of health) or the work in the laboratory (students of Science), goal protect clothing from microbes. In this study was determined the type of microbial contamination on the white coats and the potential risks of microbes. The study was done by a questionnaire for students and samples swabs of coats for 80 students from the Fac. of Health and Science. The results explained the presence of pathogenic bacteria causing inflammatory and dimples contaminated white coats, such as Erysipelothrio rhusiopathiae causing the $\mathrm{h}$ time skin, Micrococcus luteues causing chronic inflammatory skin ; bacterial meningitis and blood contamination unidentified Organism and Kocuria kristinae causing infections of the urinary tract infections, gallbladder and opportunistic bacteria and the spread of nosocomial infections, one of opportunistic pathogens. As well as recorded high proportion of serious fungi that cause various diseases and contamination of food such as Aspergillus niger; Helminthosporium spp, Fusarium $S P P$, and Alternaria alternate. This study suggests that a large proportion of white coats may be a carrier of serious morbidity among female students in colleges is different, especially when not. There are laws and regulations in organizing wear these coats and the way to carry and learn how the daily cleaning of
\end{abstract}

\section{INTRODUCTION}

White coats or lab coat is a knee-length coat of dresses worn by professionals in the medical field or on the part of participants in the work in the laboratory. Coat protects clothes at work and also the laboratory reveal professional appearance. The wear white clothing protection of colored light, and be a mix of cotton and linen, or cotton and polyester, allowing them to be washed at high temperature and make it easy to see if it is clean or not (Wear, 1998) began worn doctors. White coats in the late 19th century, when medicine flourished significantly in that area and used the doctors lab coat uniforms special their own (Blumhagen, 1979). The initial purpose was to protect the patient and the doctor of cross-contamination, after that hospitals have become centers for the treatment of patients institutions rather than to die (Chun et al 2007). Drown out this transformation remarks western culture of the concept of whiteness that deal - "Life and purity and innocence and strength hacks, and goodness and it's easy to see how White Coat became clothes favorite doctors." (Pierdomenico et al 1995 and Chun et al 2007). White coats simple kind of uniforms, and it is worn in some cases in operating rooms and in hospitals, and the Ministry of Health Act in England, as well as guidelines for the British Medical Association on the dress code for doctors to prevent nurses and doctors out of the hospital in their uniforms and considered such action murderous punishable by law (Amos, 2013). Many studies have shown that white coats and uniforms worn by health care providers often contaminated with bacteria, although there were not conclusive evidence to suggest that clothes work constitute a risk of spread of infection to patients. The white should be worn when providing health care for patients standardized uniforms should have short sleeves (Jones, 1999). Always there was a concern of some students outside the health and scientific disciplines that white

(Received 29 May, 2016)

(Revised 13 June, 2016)

(Accepted 11 August, 2016) 
coats be in health colleges and the Faculty of Science may play a role in the transfer of the bacteria that cause diseases among students as potential it holds microbes resistant to sterilizers and antibiotics and medicines (Deshmukh et al 2013) In the Other study (Bizzarro et al 2011) revealed that $60 \%$ of patients over the age of 60 dentists prefer to wear a white coat believe that the dentist must wear their white coats in comparison with those under the age of $60.30-18$ patients the doctor want to wear your teeth their white coats insatiable fear of injury in the protractor microbes from the white raincoat. (Wong et al 1991) and by monitoring the health colleges and scientific colleges notice female students wearing uniforms and coats of white outside their regions and in different areas such as libraries and areas of food available about their faculties and uncommon to see unknown white coats that were left on chairs and shelves outside work areas. Weather (1995) used databases in informatics life banks In a comparison between the $16 \mathrm{~s}$ ribosomal genes as a criterion for classification and identification of microbes, because it is present in most of the microbes and shows the appropriate changes. And it can be found on the public databases such as NCBI strains kind of $16 \mathrm{~s}$ ribosomal gene sequence of most bacteria and antique. However, often check the quality of the sequence found at these databases. Therefore, it used on a large scale secondary databases that only gathered $16 \mathrm{~s}$ ribosomal sequence (Wilson and Ho, 2013). This study aims to molecular characterization and identification of the types of microbes in white coats in each of the health colleges and the Faculty of Science at the university, hazard and causes of disease microbes from students health colleges and science to the rest of the students in different colleges and find relationships evolutionary and evolution of microbes identified from using the databases sites and building phylogenatic tree between microbes and propose strict Laws in wearing these clothes outside of work areas.

\section{MATERIAL AND METHODS}

This study was conducted in the Faculties of Health and Sciences. It has been selected 80 students randomly from different of the university stages and asked all the students to answer the questionnaire and sign a consent to take the swab.

\section{Sampling collection}

The swab carried with media was used to sampling of the white coat from the outskirts sleeved and pockets for each student and took swabs by passing up and down twice on the required areas. The three swabs were taken from each sampling. Forty samples were taken from the Fac. of Health and forty from Fac. of Sci., Dept. of Biology. The samples were incubated for $48 \mathrm{~h}$. at $37^{\circ} \mathrm{C}$ for bacteria and for 7 days at $25^{\circ} \mathrm{C}$ for fungi .

\section{Isolation of microbes}

The samples were transferred from of the swab with media on the surface of nutrient agar Petri dishes by streaking method and incubated at $37^{\circ} \mathrm{C}$ for $48 \mathrm{~h}$ for bacteria isolation. As well as the samples were transferred on the surface of Potato Dextrose Agar (PDA) medium Petri dishes by streaking method and incubated at $25^{\circ} \mathrm{C}$ for 7 days for fungi isolation.

\section{Isolation and identification of bacteria}

The swabs were streaked on to Blood agar media and incubated at $25^{\circ} \mathrm{C}$ and $37^{\circ} \mathrm{C}$ for bacterial growth. The total number of colony forming units (CFU) was estimated on each plate and pure cultures of unique colony types were obtained and saved for further analysis. The isolated bacteria were classified on the basis of their morphological and biochemical properties following Bergey's Manual of Determinative Bacteriology as well as biochemical analysis (Holt et al 2000). Vitek analyser method using VITEK® MS from bioMerieux was applied after biochemical tests as confirmatory test for bacteria, aerobic and facultative bacteria identification .

\section{Isolation and identification of fungi}

The isolated fungi were purified on Czapec and identified following the classification keys as mentioned by Pitt and Hocking (1997) and Muhadi et al (2007). The isolated fungi were identified using the implant on the glass slide and by examining the morphological characteristics and microscopic of the colony form, color, strength and type spinning innate as well as shape of spores, color and dimensions.

\section{Molecular character of isolated microbias}

The microbial carrying on coats were detected using eukaryotic and prokaryotic specific primers separately. The isolated bacteria were used to obtain 16 s amplicons by using prokaryotic universal primers 905F (5'-TGAAACTYAAAGGAATTG- 
3') and 1492R (5'-GGTTACCTTGTTACGACTT$\left.3^{\prime}\right)$ (with modifications in reference to Wang and Qian (2009). The isolated fungi were used to obtain $18 \mathrm{~s}$ amplicons by using eukaryotic primers $1 \mathrm{~A}$ (5'- AACCTGGTTGATCCTGCCAGT-3') and 564R (5'- GGCACCAGACTTGCCCTC-3') (with modifications in reference to (Medlin et al 1988). PCR conditions were modified for $16 \mathrm{~s}$ amplification, an initial denaturation at $94^{\circ} \mathrm{C}$ for $5 \mathrm{~min}$, followed by 25 cycles at $94^{\circ} \mathrm{C}$ for $50 \mathrm{~s}, 53^{\circ} \mathrm{C}$ for $50 \mathrm{~s}$ and $72^{\circ} \mathrm{C}$ for $50 \mathrm{~s}$; for $18 \mathrm{~s}$ amplification, an initial denaturation at $94^{\circ} \mathrm{C}$ for $5 \mathrm{~min}$, followed by $25 \mathrm{cy}$ cles at $94^{\circ} \mathrm{C}$ for $50 \mathrm{~s}, 59^{\circ} \mathrm{C}$ for $50 \mathrm{~s}$ and $72^{\circ} \mathrm{C}$ for 50 s. 10 ul of PCR product was electrophoresed on $1 \%$ agarose gel to determine the size of the product. The negative control consisted of all PCR components except for the template DNA.

\section{RESULTS}

The recorded evidence in Table (1) showed the result of the questionnaire students each from the Fac. of Sci. and health which users white coats through their presence at the Univ. The results were explained that about $31.25 \%$ of the students carrying the coat on their hands and $15 \%$ of them from health colleges while about $47.5 \%$ of Fac. Sci. while 2 used a special bag to put the coat after use. Scored $52.5 \%$ wearing the coat in the lab only and while $36.25 \%$ of them are wearing between the college and the lab and the college and the hospital by the students of health faculties. As shown in the Table (1) total number of times in which wash the coat were scored $60 \%$ between 2 1 once a week. $30 \%$ in the Faculty of Science wash the coat 4 times in weeks, While $27.5 \%$ wash the coat in the Faculty of Health. The Table (1) showed the detergent used to clean the coat type where he scored $50 \%$ use soap while only $10 \%$ in Fac. of Sci. and $5 \%$ in the Fac. of Health used sterilization. Also explained that the number of coats owned student who $48.75 \%$ of them possess only 2 ones.

Table (1) the results of student questionnaires in the Fac. of Sci. and health colleges users white coats during the school day. The total percentage in Fac. of Sci. 47.5; 0; 47.5; $5(\%)$ and in health colleges $15 ; 22.5 ; 62.5 ; 0$ (\%) How students are download Coat in bag; shoulder; hand and special bag respectively. The total percentage in Fac. of Sci. $90 ; 10 ; 0(\%)$ and in health colleges 15; 62.5; 22.5 (\%). Where students are using Coat in lab. Only; Lab., Hasp., Collage and all spaces respectively. The total percentage in Fac. of Sci $.62 .5 ; 7.5 ; 10$ (\%) and in health colleges $57.5 ; 15$; 27.5 (\%) number times of coat wishing, 1-2 times;
3 times; 4 times and more in weak respectively . The total percentage in Fac. of Sci. 90; 10 (\%) and in health colleges 95; 5 (\%) type of cleaning, house and cloth washer. The total percentage in Fac. of Sci. 37.5; $27.5 ; 15(\%)$ and in health colleges 62.5 ; 37.5 ; $5(\%)$ type of cleaner, Soap; Soap and ovarian and sterilized soap respectively. The total percentage in Fac. of Sci. 60; 27.5; 12.5(\%) and in health colleges $15 ; 30 ; 55(\%)$, No. of coats owned Student respectively.

Table 1. The results of students in the Faculty of Science and health questionnaire colleges users white coats during the school day.

\begin{tabular}{|c|c|c|c|c|c|}
\hline & Users & $\begin{array}{c}\text { Total } \\
\text { samples }\end{array}$ & $\begin{array}{c}\text { Fac. } \\
\text { Sci. } \\
\%\end{array}$ & \begin{tabular}{|c|} 
Fac \\
Health \\
$\%$ \\
\end{tabular} & $\begin{array}{c}\text { Total } \\
\%\end{array}$ \\
\hline $\begin{array}{l}\text { Carry the } \\
\text { coat How }\end{array}$ & $\begin{array}{l}\text { Handbag } \\
\text { Shoulder } \\
\text { Hand } \\
\text { Bag special } \\
\end{array}$ & $\begin{array}{c}25 \\
9 \\
44 \\
2 \\
\end{array}$ & $\begin{array}{c}47.5 \\
0 \\
47.5 \\
5 \\
\end{array}$ & $\begin{array}{c}15 \\
22.5 \\
62.5 \\
0 \\
\end{array}$ & $\begin{array}{c}31.25 \\
11 . .25 \\
22 \\
2.5 \\
\end{array}$ \\
\hline $\begin{array}{c}\text { Where use } \\
\text { the coat }\end{array}$ & $\begin{array}{l}\text { Laboratory } \\
\text { Lab., Hospt., } \\
\text { Collage } \\
\text { All places }\end{array}$ & $\begin{array}{l}42 \\
29\end{array}$ & $\begin{array}{l}90 \\
10\end{array}$ & $\begin{array}{c}15 \\
62.5 \\
\\
22.5 \\
\end{array}$ & $\begin{array}{l}52.5 \\
36.25 \\
11.25 \\
\end{array}$ \\
\hline $\begin{array}{l}\text { No. time of } \\
\text { the coat } \\
\text { washing } \\
\end{array}$ & $\begin{array}{l}\text { 1-2 times in week } \\
\text { 3-times in week- } \\
4 \text { times in week }\end{array}$ & $\begin{array}{c}48 \\
9 \\
23 \\
\end{array}$ & $\begin{array}{c}62.5 \\
7.5 \\
30 \\
\end{array}$ & $\begin{array}{c}57.5 \\
15 \\
27.5 \\
\end{array}$ & $\begin{array}{r}60.0 \\
11.25 \\
28.25 \\
\end{array}$ \\
\hline $\begin{array}{l}\text { Type of } \\
\text { cleaning }\end{array}$ & $\begin{array}{l}\text { House } \\
\text { Laundry }\end{array}$ & $\begin{array}{c}74 \\
6 \\
\end{array}$ & $\begin{array}{l}90 \\
10 \\
\end{array}$ & $\begin{array}{c}95 \\
5 \\
\end{array}$ & $\begin{array}{c}92.5 \\
7.5 \\
\end{array}$ \\
\hline Cleaner & $\begin{array}{l}\text { Soap } \\
\text { Soap and ovari- } \\
\text { an } \\
\text { Sterilized Soap } \\
\end{array}$ & $\begin{array}{l}40 \\
23\end{array}$ & $\begin{array}{r}37.5 \\
27.5 \\
\\
15 \\
\end{array}$ & $\begin{array}{l}62.5 \\
32.5\end{array}$ & $\begin{array}{r}50 \\
40 \\
10.0 \\
\end{array}$ \\
\hline $\begin{array}{c}\text { No. of coats } \\
\text { owned } \\
\text { Student }\end{array}$ & $\begin{array}{l}\text { One } \\
\text { Two } \\
\text { More than one }\end{array}$ & $\begin{array}{l}30 \\
23 \\
27\end{array}$ & $\begin{array}{c}60 \\
27.5 \\
12.5\end{array}$ & $\begin{array}{l}15 \\
30 \\
55\end{array}$ & $\begin{array}{r}37.5 \\
48.75 \\
33.75\end{array}$ \\
\hline
\end{tabular}

\section{Identification of isolated bacteria}

Aerobic and facultative bacteria isolated from white coats of students in the Fac. of Sci. and health using during the school day were identified using morphological and cultures characters. For a more precise and accurate classification and identification of the isolated bacteria since Vitek analyser method using VITEK® MS attributes showed some variability. Molecular techniques of DNA sequencing was successfully amplified from 
bacteria isolates using universal primers and separated on gel for verification. Sequencing of $16 \mathrm{~s} r$ DNA sequences were conducted using the same primers which were use for amplification. Accordingly, the phylogenetic relationship of the bacteria isolates was studied.

The eleven different 16s $r$ DNA sequences were aligned with sequences of other bacteria isolates obtained from the Genbank and a phylogenetic tree was done for relationship between isolated bacteria. The pairwise alignment (Fig. 1) of the obtained sequences with sequences in database showed that obtained sequences were identified Leuconostoc mesenteroides spcremoir HG937753.1; Granulicatella elegans YI5413.1; Aeromonas salmonicida HG941669.1; Derma- coccus nishinomiyaensis HE716916.1; Micrococcus luteues LN835461.1; Kocuria kristinae AJ316579.1 and Kocuriar osea LN774766.1. Finger (1) illustrated the phylogenic tree for isolated bacteria by genetic distance based on nucleotide sequence. The phylogenic tree include two major groups. the first group included Leuconostoc mesenteroides spcremoir HG937753.1 and Granulicatella elegans. The major secand group included three subgroups, the first subgroup, Aeromonas salmonicida; the second subgroup Dermacoccus nishinomiyaensis and Micrococcus luteues and third subgroup Kocuria kristinae and Kocuriar osea with related similarity 0.28 genetic distance.

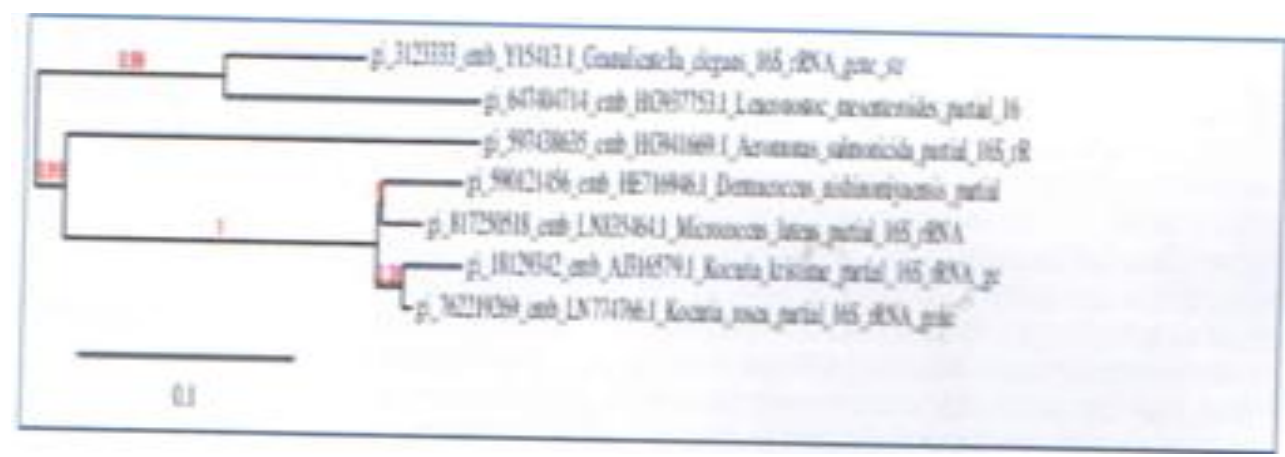

Fig. 1. The phylogenic tree for isolated bacteria by genetic distance based on nucleotide sequence.

\section{Identification of isolated fungi}

Filamentous fungi were isolated from white coats of students in the Fac. of Science and health using during the school day. Isolated fungi were identified using morphological and cultures characters . For a more precise and accurate classification and identification of the isolated fungi since morphological and cultures characters attributes showed some variability, molecular techniques of DNA sequencing were applied. DNA was successfully amplified from fungi isolates using universal primers and separated on gel for verification. Sequencing of $18 \mathrm{~s} r$ DNA sequences were conducted using the same primers which were use for amplification. Accordingly, the phylogenetic relationship of the bacteria isolates was studied.

The eleven different 18s $r$ DNA sequences were aligned with sequences of other fungi isolates obtained from the Genbank and a phylogenetic tree was done for relatiomship between isolated fungi.
The pairwise alignment of the obtained sequences with sequences in database showed that obtained sequences were identified Aspergillus niger; Alternaria spp; Fusarium spp; Helminthosporium spp and Penicillium spp (Figs. 2 and 3). Finger (2) illustrated the phylogenic tree for isolated Aspergillus sp Saudi Arabia isolate with other isolates recorded in Gene Bank by genetic distance based on nucleotide sequence 18s rRNA gene. It included two groups, the first group included Aspergillus clavatus 0.14 and Aspergillus fumigates 0,02 genetic distance. The second group Aspergillus sp Saudi Arabia Isolate by 0.18 genetic distance.

Finger (3) illustrated the phylogenic tree for isolated Penicillium sp Saudi Arabia isolate other isolates recorded in Gene Bank by genetic distance based on nucleotide sequence 18s rRNA gene. It included two groups, the first group included Penicillium sp Saudi Arabia isolate and Micron onospora KP784801 by 0.03 genetic distance. The second group Penicillium chrysogenum AM920417 . 


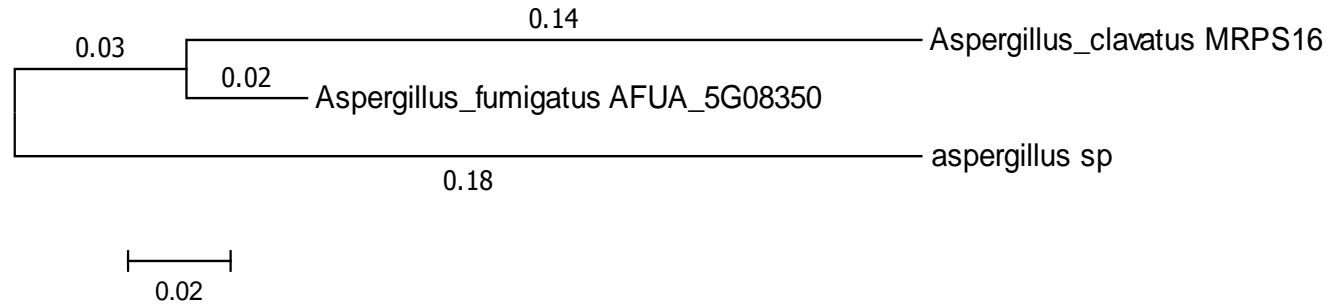

Fig. 2. The phylogenic tree for isolated Aspergillus sp Saudi Arabia isolate and other isolates recorded in Gene Bank by genetic distance based on nucleotide sequence 18s rRNA gene.

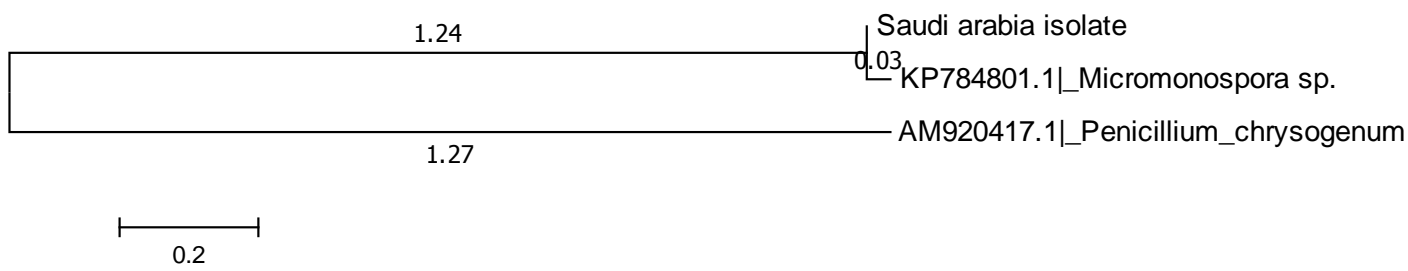

Fig. 3. The phylogenic tree for isolated Penicillium sp and other isolates recorded in Gene Bank by genetic distance based on nucleotide sequence 18s rRNA gene.

\section{DISCUSSION}

This research a high percentage of students knitted unaware of health the way for movement in the lab coat saluting between the number of female students who have coats in the bag percentage high compared to those using a special bag percentage does not exceed $2 \%$, and through it we found that students in the Faculty knitted science using coats in the lab only contamination high fungal compare the health colleges ratio may due to wearing apron can be disposed of immediately after the completion of which Examples of fungi existing heavily on the coat white fungus Alternaria $\mathrm{sp}$ which causes human health disorders through these fungi that grow on the skin and mucous membranes (Germán et al 2008), and also mushroom Fusarium spp which is in turn urges and produces toxins that affect blood circulation, skin and nervous system and lead to hemorrhagic syndrome. As well as the reasons that helped the presence of microbes in Coats students because this is due to the ratio of the number of times the coat laundering and ranges from once to twice a week by about $60 \%$ and found these are percentage in students in the Faculty of Science As for the students of Medical Colleges, the pollution slicker and more the proportion exceed $28 \%$ of the spec- trum is due to the number of times the laundry. In our question to the students about the place clean coats and we found that a high percentage of students using the house in clean coats more of the special sinks by $90 \%$ and through it we found that the majority of students only use soap to clean the coats of sterile soap in both the health colleges and the Faculty of Science. And also we found the number of coats that I am possessed by the students and one coat instead of a third Coats and owning more. A possible transition of infection in health colleges and back and from the above it can be said that the white coats are considered the piece because of the presence of the students in hospital training period, indicating the reason for the presence of this bacteria on the white coats and an example of this bacteria Aeromonas salmonicida which in turn is not responding to antibiotics, which increases the proportion of gravity on the human body and also Kocuria kristinae bacteria that cause infections of the urinary tract infections and bitterness of the above can be said that the white coats are considered a potential source of microbes move in different parts of the colleges, according to studies made clear (Blumhagen,1979 and Quinn et al 2002). Allen student moves from one college to another wearing a coverall White loaded with microbes nurse and through that this 
helps to spread faster and private places crowded by students and by the results phenomenon must take off the coat white before coming out of the plants and contaminated centers and place it in a special bag so hard to spread microbes (Wong et al 1991) As the results showed that the bacteria Sphingomonas paucimobillis most spread of nosocomial infections, and also bacteria Kocuria rosea is causing diseases not be as in patients with weakened immune they can cause opportunistic infections and bacteria that are difficult to get rid of them or by antibiotics or get rid him if were stuck in the coat or in hand through detergents, disinfectants and bacterial resistance to antibiotics Aeromonas salmonicida, which in turn cause diarrhea and infections stomach (Andre, 2012), but by the fungus example fungus Alternaria spp that grows on the skin and mucous membranes and cause hypersensitivity, and the fungus Alternaria alternate cause infections of the respiratory tract and through this note that the proportion of microbial contamination for the students of the Faculty of Science for students of higher colleges of health and especially as they commit their students to wear and get rid of them immediately after the completion of them .

The types of pathogenic bacteria that are defined bacteria causing disease Leuconostoc mesenteroides ssp cremoir opportunistic infections and private patients in weakened immune called nosocomial infections claim to death mostly. (Quinn et al 2002). Erysipelothrio rhusiopathiae the $\mathrm{h}$ time of skin caused blushes sumaghiyyeh disease, one of the diseases transmitted from animals to human (Acha, and Szyfres, 1989). Micrococcus luteus cause problems such as shock Aallantnah, and pneumonia and endocarditis or sepsis (Glupczynski et al 1986). Unidentified 4 Organism meningitis and blood contamination Aeromonas salmonicida resistant to antibiotics and cause diarrhea and infections stomach (Amos, 2011). Pasteuella canis pathogens opportunism that can cause diseases endemic, increasingly linked with an outbreak Epidemiological may also cause abscesses under the skin that can be chronic (Wilson and Ho, 2013). Granulicatella elegans and septicemia or bacteremia and ulceration of the mouth and dimples Kocuria rosea symptoms caused by these bacteria that may be higher than previously thought at the moment, given that the difficulty identified During tests in biology and microscopic estimated prevalence over the years. Basis and that the guidelines for treatment of diseases involving the types Kocuria non-existent, mainly due to the lack of con- sistent standards to assess Kocuria copies or inhibition of growth in the presence of antibiotics (Dotis, et al 2012). It also caused peritonitis Rosary for children peritoneal dialysis patients (Vincenzo et al 2010). Dermacoccus nishinomiyaensis infections of the skin Kocuria kristinae 10 urinary tract infections and inflammation of the gallbladder Sphingomonas paucimobillis of the most prevalent nosocomial infections. They pathogens opportunism that benefit from the underlying conditions and diseases, the types of pathogenic fungi that have been defined $m$ Name mushroom illnesses causing her Aspergillus spp is a common cause of respiratory tract irritation and inflammation. They Allergy common. Alternaria SPP reason many Human health disorders through these fungi that grow on the skin and mucous membranes and causes hay fever or hypersensitivity (Wilson and Ho, 2013). Alternaria SPP and Aspergillus niger cause of many human health disorders through these fungi that grow on the skin and mucous membranes, and cause hay fever or hypersensitivity - cause my ear disease) ear fungal infections (which can cause pain, loss of the interim hearing , Alternaria alternate cause upper respiratory tract infections Alternaria alternate cause upper respiratory tract Helminthosporium spp. and Alternaria spp causes the southern blight plant reason many-of human health disorders through these fungi that grow on the skin and mucous membranes, and cause hay fever or hypersensitivity corn Alternaria spp cause of many human health disorders through these fungi that grow on the skin and mucous membranes and causes hay fever or hypersensitivity Pencillium spp rarely What causes the disease, but after skin damage, may multiply inside and cause ulcerative pests. Fusarium spp and very detrimental to Balsam where it produces toxins affect the blood circulation, the skin and nervous system and lead to the syndrome of hemorrhagic) Symptoms include nausea, vomiting, skin inflammation, internal bleeding and a large-scale (and also infect human allergies and is often associated with eye infections, skin and nails (Wear, 1998 and Wong et al 1991).

\section{REFERENCES}

Acha, P.N. and Szyfres, B. 1989. Zoonoses and Communicable Diseases Common to Man and Animals. Pan American Health Organization; Washington, D.C. pp. 345-356.

Amos. K. 2013. Disease interactions of wild and cultivated salmon. http://www.psmfc.org/ 
ans presentations/AmosK.pdf Accessed on 14 August 2013

Andre, P. 2012. Why do physicians wear white lab coats"? .The Globe and Mail.10-11-2012.

Bizzarro, M.J., Callan, D.A., Farrel, P.A., Dembry, L.M. and Gallagher, P.G. 2011. Granulicatella adiacens and early-onset sepsis in neonate. Emerg Infect Dis; 17, 3110-3201.

Blumhagen, D.W. 1979. The doctor's white coat. The image of the physician in modern America. Ann. Intern. Med., 91, 95-119.

Chun, J.; Lee, J.H.; Jung, Y.; Kim, M.; Kim, S.; Kim, B.K.; Lim, Y.W. 2007. "EzTaxon: a webbased tool for the identification of prokaryotes based on 16S ribosomal RNA gene sequences". Int. J Syst. Evol Microbiol 57, 22592261.

Deshmukh, S., Anshul, S., Vikas, S., Pallavi, T. and Harish, T. 2013. Should Dentist wear white coat or not? A cross-sectional study. IOSR Journal of Dental and Medical Sciences,10, Issue 1 (Sep.- Oct. 2013), 37-40.

Dotis, J.; Printza, N. and Papachristou, F., 2012. Peritonitis Attributable to Kocuria rosea in a Pediatric Peritoneal Dialysis, pp. 235-423.

Germán, B., Luis Saleta, J., Juan, A., Mar, T., Silvia, V., Dolores, S., Francisco, L., Rosa, V., Maria, J. and Pedro, L. 2008. NosocomialOutbreaks Caused by Leuconostoc mesenteroides subsp. mesenteroides. Emerging Infectious Diseases, 14( 6),132-146.

Glupczynski, Y., Lagast, H., Van der Auweram P., Thys J.P., Crokaert F., Yourassowsky E., Meunier-Carpentier F., Klastersky J., Kains J.P., Serruys Schoutens E. 1986. Clinical evaluation of teicoplanin for therapy of severe infections caused by gram-positive bacteria. Antimicrob Agents Chemother, 29(1), 52-57.

Holt, J.G., Krieg, N.R., Sneath, P.H.A.; Stanley, J.T. and Williams,S.T. 2000. Bergey ${ }^{1} s$ manual of determinative bacteriology $\left(9^{\text {th }}\right.$ ed. Williams and Wilkins, Baltimore)

Jones , V.A. 1999. "The White Coat: Why not Follow Suit?" JAMA. 281, 478-482.
Medlin, L., Elwood, H.J., Stickel, S. and Sogin, M.L. 1988. The characterization of enzymaticcally amplified eukaryotic 16S-like rRNA-coding regions. Gene 71, 491-499.

Muhadi, S.A., Aanamshah, N.A. and Jahanfar, S.A. 2007. A cross sectional study on the microbial contamination of the medical student's white coats. Malayasian Journal of Microbiology. 1, 38-35.

Pierdomenico, S., Mezzetti, A., Lapenna, D., Guglielmi, M., Mancini, M., Salvatore, L., Antidormi, T., Costantini, F. and Cuccurullo, F. 1995. "'White-coat' hypertension in patients with newly diagnosed hypertension: evaluation of $p$ prevalence by ambulatory monitoring and impact on cost of health care.".Eur Heart J. 16, 692-697.

Pitt, J.I. and Hocking A.D. 1997. Fungi and food Spoilage. Blackie Academic Professional, pp. 366-368.

Quinn, P.J., Carter. M.G., Markey, B. and Carter, G.R. 2002. Clinical Veterinary Microbiology, M. Wlof, London. pp. 563-600

Vincenzo, S., Chiara, C., Gioviana, M., Daniela, A. Andrea, B., Azaira, B., Fabio, F., Claudio and Domenico, D. 2010. Drug sensitivity and clinical impact of members of the genus Kocuria J. Med Microbiol. 59(Pt 12),1395-1402.

Wang. Y. and Qian P.Y. 2009. Conservative fragments in bacterial 16S rRNA genes and primer design for $16 \mathrm{~S}$ ribosomal DNA amplicons in metagenomic studies. PLoS ONE 4,74014713.

Wear, D. 1998. On white coats and professional development: the formal and the Hidden curricula. Ann Intern Med., 129,734-737.

Weather, D. 1995. Science and the quiet art. Medical research and patient care. Oxford: Oxford University PRESS, 5,55-88

Wilson, B.A. and Ho M., 2013. Pasteurella multocida: from zoonosis to cellular microbiology, Clin Microbiol Rev. 26(3),631-655.

Wong, D,Nye K. and Hollis, P.,1991. The microbial flora on dector's white coats. British Medical Journal. 303, 21-28. 